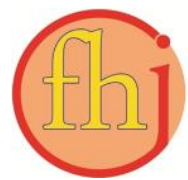

Faletehan Health Journal, 8 (2) (2021) 115-121

www. journal.Ippm-stikesfa.ac.id/ojs/index.php/FHJ

ISSN 2088-673X | e-ISSN 2597-8667

\title{
Analisis Hubungan antara Usia Kehamilan, Berat Lahir Bayi, Jenis Persalinan dan Pemberian Asi dengan Kejadian Hiperbilirubinemia
}

\author{
Husnul Khotimah ${ }^{1 *}$, Sri Utami Subagio ${ }^{1}$ \\ ${ }^{1}$ Program Studi DIII Kebidanan, Universitas Faletehan \\ *Corresponding Author: husnulmehu@gmail.com
}

\begin{abstract}
Abstrak
Hiperbilirubinemia merupakan salah satu penyebab kematian bayi yang terbanyak, disebabkan oleh kegawatdaruratan dan penyulit pada neonatus. Banyak faktor yang mempengaruhi Hiperbilirubinemia sebetulnya dapat dicegah. Penelitian ini bertujuan untuk mengetahui hubungan antara usia kehamilan, berat lahir bayi, jenis persalinan dan pemberian ASI dengan kejadian hiperbilirubinemia pada bayi di ruang perinatologi Rumah Sakit Umum Daerah dr. Drajat Prawiranegara tahun 2020. Penelitian ini merupakan penelitian analitik dengan desain case control. Populasi penelitian ini adalah seluruh bayi yang dirawat di ruang perinatologi sebanyak 14.937 bayi. Besar sampel dihitung dengan menggunakan rumus uji hipotesis odd ratio, mendapatkan hasil 22. Jumlah sampel kasus sebanyak 22 bayi dan kontrol sebanyak 44 bayi (1:2) sehingga total sampel sebanyak 66 bayi. Analisis data bivariat menggunakan chi square dan multivariat menggunakan regresi logistik berganda. Hasil penelitian menunjukkan terdapat hubungan yang bermakna antara usia kehamilan $(P: 0,006)$, berat lahir bayi $(P: 0,002)$, jenis persalinan $(P: 0,001)$ dan pemberian $A S I(P: 0,000)$ dengan kejadian hiperbilirubinemia. Faktor dominan yang berpengaruh terhadap kejadian hiperbilirubinemia adalah pemberian ASI. Inisiasi menyusui dini (IMD) dan memotivasi ibu dengan bayi yang mengalami hiperbilirubinemia untuk tidak panik serta tetap memberikan ASI on demand menjadi upaya yang dapat dilakukan dalam mengurangi hiperbilirubinemia.
\end{abstract}

Kata Kunci: Berat Lahir Bayi, Hiperbilirubinemia, Jenis Persalinan, Pemberian Asi, Usia Kehamilan

\section{Analysis of Relationship between Gestational Age, Birth Weight, Type of Childbirth and Breastfeeding with Occurrence of Hyperbilirubinemia}

\begin{abstract}
Hyperbilirubinemia is one of the most common causes of infant death, caused by emergencies and complications in neonates. Many factors that influence Hyperbilirubinemia are preventable. This research aims to determine the relationship between gestational age, birth weight, type of childbirth and breastfeeding with the occurrence of hyperbilirubinemia in infants at the perinatology ward of Doctor Drajat Prawiranegara Regional General Hospital in 2020. This research is analytical with a case control design. The study population was all infants treated at the perinatology ward as many as 14,937 babies. The sample size was calculated using the odds ratio hypothesis test formula, obtained 22. The number of case samples was 22 babies and the control was 44 babies (1:2), so the total samples were 66 babies. The bivariate data analysis used chi square and the multivariate used multiple logistic regression. The research result showed there was a significant relationship between gestational age (P:0.006), birth weight ( $P: 0.002)$, types of childbirth ( $P: 0.001)$ and breastfeeding $(P: 0.000)$ with the occurrence of hyperbilirubinemia. The dominant factor affecting the occurrence of hyperbilirubinemia is breastfeeding. Early initiation of breastfeeding and motivating mothers with baby with hyperbilirubinemia not to panic and continue to breastfeed on demand are efforts to reduce hyperbilirubinemia.

Keywords: Birth Weight, Hyperbilirubinemia, Type of Childbirth, Breastfeeding, Gestational Age
\end{abstract}




\section{Pendahuluan}

Angka Kematian Bayi (AKB) di Indonesia terus menurun setiap tahun. Namun, jalan memerangi AKB masih panjang. Hasil Survei Demografi dan Kesehatan Indonesia (SDKI) menunjukkan dari tahun ke tahun AKB mengalami penurunan signifikan. Dari 68 kematian per 1.000 kelahiran hidup pada 1991, hingga 24 kematian per 1.000 kelahiran hidup pada tahun 2017 (Kementrian Kesehatan RI 2017). Jumlah kematian neonatal di Provinsi Banten tahun 2016 sebesar 874 per 1.000 kelahiran hidup, dan jumlah kematian neonatal di Kabupaten Serang masih terbilang cukup tinggi yaitu 141 per 1.000 kelahiran hidup (Dinas Kesehatan Provinsi Banten 2017).

Hiperbilirubinemia merupakan salah satu penyebab kematian bayi yang terbanyak disebabkan oleh kegawatdaruratan dan penyulit pada neonatus. Berdasarkan data di RSUD Drajat Prawiranegara Kabupaten Serang Provinsi Banten pada tahun 2019, kasus hiperbilirubin merupakan kasus tertinggi yaitu sebanyak 757 bayi dari total seluruh bayi yang dirawat di ruang perinatologi sebanyak 2764 bayi (Prawiranegara 2019). Peningkatan kadar bilirubin dalam darah yang kadar nilainya lebih dari normal disebut dengan hiperbilirubinemia. Nilai normal bilirubin indirek $0,3-1,1 \mathrm{mg} / \mathrm{dl}$ dan bilirubin direk $0,1-0,4 \mathrm{mg} / \mathrm{dl}$. Hiperbilirubinemia merupakan keadaan normal pada bayi baru lahir selama minggu pertama, karena belum sempurnanya metabolisme bilirubin bayi (Maryunani 2014).

Hiperbilirubinemia dipengaruhi oleh factor usia kehamilan, asfiksia, trauma lahir, berat lahir bayi, infeksi, dan hipoglikemi. Sedangkan, efek sampingnya bisa terjadi Ensefalopati dan Kern Ikterus (Maryunani 2014). Sectiocaesaria dihubungkan secara tidak langsung dengan hiperbilirubinemia, dimana persalinan sectio caesaria akan menunda ibu untuk menyusui bayinya, yang kemudian dapat berdampak pada lambatnya pemecahan kadar bilirubin (Roselina 2013).

Berdasarkan survei pendahuluan yang dilakukan terhadap 4 ibu yang datang menjenguk bayinya di ruang perinatologi Rumah Sakit Umum Daerah (RSUD) Drajat Prawiranegara didapatkan hasil bahwa bayi yang mengalami hiperbilirubin sebagian besar dilahirkan dengan usia kehamilan kurang dari 37 minggu, lahir dengan berat badan kurang dari 2500 gram, dilahirkan secara sectio cesarea dan bayi tidak diberi ASI. Dengan demikian dapat dirumuskan pertanyaan penelitian bagaimana hubungan antara usia gestasi, berat lahir bayi, jenis persalinan dan pemberian ASI dengan kejadian hiperbilirubin pada bayi di Rumah Sakit Umum Daerah (RSUD) Drajat Prawiranegara tahun 2020?. Penelitian ini bertujuan untuk mengetahui hubungan antara usia kehamilan, berat lahir bayi, jenis persalinan dan pemberian ASI dengan kejadian hiperbilirubin pada bayi di ruang perinatologi Rumah Sakit Umum Daerah (RSUD) Drajat Prawiranegara tahun 2020.

\section{Metodologi Penelitian}

Desain yang digunakan dalam penelitian ini adalah analitik dengan pendekatan case control. Populasi dalam penelitian ini adalah seluruh ibu dari bayi yang dirawat di ruang perinatologi RSUD Drajat Prawiranegara sebanyak 14.937 bayi. Jumlah Sampel pada penelitian ini ditentukan dengan menggunakan sampel minimal, dihitung dengan menggunakan rumus uji hipotesis odd rasio dengan hasil 22. Sampel penelitian ini adalah 22 sampel kasus dan 44 sampel kontrol sehingga total sampel 66 bayi, teknik pengambilan sampel yaitu kuota sampling. Pengumpulan data dilakukan dengan pengisian kuesioner oleh responden yaitu ibu bayi yang dirawat di ruang perinatologi RSUD Drajat Prawiranegara untuk mengetahui variabel pemberian ASI (data primer) dengan jumlah butir pertanyaan sebanyak 6 butir yang menanyakan tentang frekuensi dan kualitas pemberian ASI, sedangkan untuk variabel kasus hiperbilirubin, usia kehamilan, berat lahir bayi dan jenis persalinan dilihat dari buku status pasien (data sekunder).

Analisis data univariat dalam bentuk frekuensi, dilanjutkan dengan analisis bivariat dengan menggunakan chi square, dan multivariat dengan teknik regresi logistik berganda. Penelitian di lakukan di Ruang Perinatalogi RSUD Drajat Prawiranegara pada bulan Februari sampai dengan Mei 2020.

\section{Hasil dan Pembahasan}

Berdasarkan tabel 1 didapatkan bahwa terdapat hampir setengah dari frekuensi mengalami hiperbilirubin, usia kehamilan preterm, lahir dengan berat badan lahir rendah (BBLR), jenis persalinan tidak normal dan tidak diberi ASI. 
Faletehan Health Journal, 8 (2) (2021) 115-121

Tabel 1: Distribusi Frekuensi Responden

\begin{tabular}{|c|c|c|}
\hline \multirow[t]{2}{*}{ Kategori } & \multicolumn{2}{|c|}{$\begin{array}{l}\text { Kelompok } \\
\text { Responden }\end{array}$} \\
\hline & $\mathbf{n}$ & $\%$ \\
\hline \multicolumn{3}{|l|}{ Kejadian Hiperbilirubin } \\
\hline Hiperbilirubin & 22 & 33,3 \\
\hline Tidak hiperbilirubin & 44 & 66,7 \\
\hline \multicolumn{3}{|l|}{ Usia Kehamilan } \\
\hline Preterm $(<37$ minggu $)$ & 20 & 0,3 \\
\hline Aterm $(\geq 37 \mathrm{minggu})$ & 46 & 69,7 \\
\hline \multicolumn{3}{|l|}{ Berat lahir bayi } \\
\hline BBLR & 21 & 31,8 \\
\hline Tidak BBLR & 45 & 68,2 \\
\hline \multicolumn{3}{|l|}{ Jenis Persalinan } \\
\hline $\begin{array}{l}\text { Tidak Normal (SC, } \\
\text { Vakum) }\end{array}$ & 34 & 51,5 \\
\hline Normal (Pervaginam) & 32 & 48,5 \\
\hline \multicolumn{3}{|l|}{ Pemberian ASI } \\
\hline Diberi ASI & 18 & 27,3 \\
\hline Tidak diberi ASI & 48 & 72,7 \\
\hline
\end{tabular}

\section{Hubungan antara Usia Kehamilan dengan Kejadian Hiperbilirubin}

Tabel 2 menunjukan bahwa kejadian hiperbilirubin proporsinya lebih besar terjadi pada usia kehamilan Preterm ( $<37$ minggu) yaitu $54,5 \%$. Hasil uji statistik dengan menggunakan $C h i$ Square pada $\alpha=0,05$ didapatkan nilai $\mathrm{P}$ sebesar $0,006(\mathrm{P}<0,05)$ yang berarti bahwa secara statistik terdapat hubungan yang bermakna antara usia kehamilan dengan kejadian hiperbilirubin. Nilai OR menunjukkan hasil 5,4 artinya usia kehamilan Preterm memiliki peluang 5 kali lebih besar menyebabkan bayi mengalami hiperbilirubin dibandingkan dengan usia kehamilan Aterm.

Usia gestasi (masa kehamilan) yaitu masa terjadinya konsepsi sampai pada saat kelahiran, di hitung dari hari pertama haid terakhir (menstrual age of pregnancy) atau usia kehamilan (gestational age) adalah ukuran lama waktu seorang janin berada dalam rahim (Marmi 2012). Usia kehamilan merupakan faktor yang penting dan penentu kualitas kesehatan bayi yang dilahirkan, karena bayi baru lahir dari usia kehamilan yang kurang berkaitan dengan berat lahir rendah dan tentunya akan berpengaruh kepada daya tahan tubuh bayi yang belum siap menerima dan beradaptasi dengan lingkungan di luar rahim sehingga berpotensi terkena berbagai komplikasi salah satunya adalah ikterus neonatorum yang dapat menyebabkan hiperbillirubinemia (Cholifah and Hadikasari 2016).

Hasil penelitian factor resiko kejadian hiperblirubin di Iran menjelaskan bahwa secara signifikan usia kehamilan berkaitan dengan kejadian hiperbilirubin, bayi yang dilahirkan saat usia kehamilan < 37 minggu. Semakin cukup usia kehamilan ibu maka bayi yang dilahirkan akan semakin matang fungsi organnya sehingga kemungkinan terjadinya hiperbilirubin sangat rendah, pada bayi yang belum cukup bulan yakni proses pengeluaran bilirubin melalui organ hepar yang belum matang menyebabkan terjadinya penumpukan bilirubin (Siyah Bilgin et al. 2013). Hal ini sejalan dengan penelitian menurut (Roselina, 2013) yang menyatakan bahwa terdapat hubungan antara usia kehamilan dengan kejadian hiperbilirubin (Roselina 2013).

\section{Hubungan antara Berat Lahir Bayi dengan Kejadian Hiperbilirubin}

Tabel 3 menunjukan bahwa kejadian hiperbilirubin proporsinya lebih besar pada bayi dengan BBLR (59\%) dibandingkan bayi yang tidak BBLR (41 \%). Hasil uji statistik dengan menggunakan Chi Square pada $\alpha=0,05$ didapatkan nilai $\mathrm{P}$ sebesar $0,002(\mathrm{P}<0,05)$ yang berarti bahwa secara statistik terdapat hubungan yang bermakna antara berat lahir bayi dengan kejadian hiperbilirubin. Dan didapatkan hasil OR 6,500 artinya bayi BBLR memiliki peluang 6 kali lebih besar untuk bayi mengalami hiperbilirubin dibandingkan dengan bayi tidak BBLR.

Pada bayi lahir, karena usia kehamilan merupakan faktor yang penting dan penentu kualitas kesehatan bayi yang dilahirkan, karena bayi baru lahir dari usia kehamilan yang kurang berkaitan dengan berat lahir rendah dan tentunya akan berpengaruh kepada daya tahan tubuh bayi yang belum siap menerima dan beradaptasi dengan lingkungan di luar rahim sehingga berpotensi terkena berbagai komplikasi salah satunya adalah ikterus neonatorum yang dapat menyebabkan hiperbillirubinemia (Cholifah 2017).

Bayi yang memiliki Berat Badan Lahir Rendah (BBLR) tanpa memandang masa gestasinya baik itu bayi prematur atau cukup bulan dapat menyebabkan tidak adanya atau berkurangnya jumlah enzim yang diambil atau menyebabkan pengurangan reduksi bilirubin oleh sel hepar, selain itu pada BBLR kenaikan bilirubin serum cendrung sama atau sedikit lebih lambat dari 
pada kenaikan bilirubin pada bayi cukup bulan tetapi jangka waktunya lebih lama yang biasanya mengakibatkan kadar bilirubin yang lebih tinggi (Sulistyorini 2018). BBLR sangat rentan mengalami komplikasi yaitu sindrom aspirasi mekonium, hipoglikemi simptomatik penyakit membran hialin, asfiksia, neonatorum, hyperbilirubinemia atau ikterus (Indrasari 2016).

Penelitian lain menyebutkan bahwa Hiperbilirubin pada kasus bayi baru lahir rendah biasanya lebih berkembang lebih awal dan bertahan lebih lama dan membutuhkan fototerapi yang berkepanjangan pada bayi berat lahir rendah bahkan hingga kebutuhan transfusi jika dibandingkan dengan kasus hiperbilirubin yang terjadi pada bayi dengan berat badan lahir normal (Khan et al. 2014). Penelitian lainnya menyebutkan hal yang sama bahwa pada bayi dengan berat badan lahir rendah maka kadar bilirubin lebih tinggi hal tersebut dikarenakan fungsi organ yang belum cukup matang dan metabolism enzyme yang tidak bekerja secara maksimal sehingga meningkatkan kadar bilirubin (Nurani, Kadi, and Rostini 2017).

Kematangan pada organ bayi yang BBLR belum maksimal dibandingkan dengan bayi yang memiliki berat badan lahir normal. Proses pengeluaran bilirubin melalui organ hepar yang belum matang menyebabkan terjadinya ikterus pada bayi. Sehingga terjadi penumpukan bilirubin dan menyebabkan warna kuning pada permukaan kulit (Madiastuti and Chalada 2018).

\section{Hubungan antara Jenis Persalinan dengan Kejadian Hiperbilirubin}

Tabel 4 menunjukan bahwa kejadian hiperbilirubin proporsinya lebih besar pada ibu dengan jenis persalinan tidak normal $(81,8 \%)$ dibandingkan dengan jenis persalinan normal $(18,2$ $\%)$. Hasil uji statistik dengan menggunakan Chi Square pada $\alpha=0,05$ didapatkan nilai $\mathrm{P}$ sebesar $0,001 \quad(\mathrm{P}<0,05)$ yang berarti bahwa secara statistik terdapat hubungan yang bermakna antara jenis persalinan dengan kejadian hiperbilirubin. Dan didapatkan hasil OR 7,875 artinya responden dengan jenis persalinan tidak normal memiliki peluang hampir 8 kali lebih besar menyebabkan bayi mengalami hiperbilirubin dibandingkan dengan jenis persalinan normal.

Hubungan jenis persalinan sectiocaesaria dengan hiperbilirubinemia memiliki hubungan yang tidak langsung, dimana persalinan sectio caesaria akan menunda ibu untuk menyusui bayinya, yang kemudian dapat berdampak pada lambatnya pemecahan bilirubin (Roselina 2013). Menurut penelitian Bilgin (2013) bahwa bayi prematur atau bayi cukup bulan yang dilahirkan dengan section caesaria terdapat waktu pemberian nutrisi dalam hal ini ASI yang terlambat dan lebih sering diberi makan campuran yakni diberi tambahan susu formula mengalami peningkatan kadar bilirubin sehingga dapat menyebabkan terjadinya hiperbilirubin (Siyah Bilgin et al. 2013).

Referensi lain pun sejalan dengan hasil penelitian yang telah disebutkan sebelumnya bahwa pada saat ibu dengan proses persalinan sectio caesaria menunda untuk menyusui bayinya, hal tersebut tentu berakibat pada bayi yang seharusnya sudah diberikan ASI saat 3 jam pertama dan diharapkan dalam 4 jam berikutnya sudah mengeluarkan meconium karena 1 gram mekonium basah mengandung $1 \mathrm{mg}$ bilirubin, keterlambatan pengeluaran mekonium dan penurunan frekuensi aliran mekonium dapat meningkatkan sirkulasi enterohepatik dan berkontribusi pada perkembangan peningkatan hiperbilirubin. Dan didapatkan pula hasil bahwa 32 bayi lahir pervaginam dan 30 bayi lahir secara sectio caesaria, bayi lahir pervaginam lebih dahulu dalam pengeluaran meconium (Siyah Bilgin et al. 2013).

\section{Hubungan antara Pemberian ASI dengan Kejadian Hiperbilirubin}

Berdasarkan tablel 5 menunjukan bahwa kejadian hiperbilirubin proporsinya lebih besar pada bayi yang tidak diberi ASI $(72,7 \%)$ dibandingkan dengan bayi yang diberi ASI (27,3 $\%)$. Hasil uji statistik dengan menggunakan Chi Square pada $\alpha=0,05$ didapatkan nilai $\mathrm{P}$ sebesar $0,000(\mathrm{P}>0,05)$ yang berarti bahwa secara statistik terdapat hubungan yang bermakna antara pemberian ASI dengan kejadian hiperbilirubin dan didapatkan hasil OR 56,000 artinya bayi yang tidak diberi ASI memiliki peluang hampir 56 kali lebih besar menyebabkan bayi mengalami hiperbilirubin dibandingkan dengan bayi yang diberi ASI.

Variabel pemberian ASI, hasil uji statistik dengan menggunakan Chi Square pada $\alpha=0,05$ didapatkan nilai $\mathrm{P}$ sebesar $0,000(\mathrm{P}<0,05)$ yang berarti bahwa secara statistik terdapat hubungan yang bermakna antara pemberian ASI dengan kejadian hiperbilirubin. Pada hasil penelitian ini menunjukan bahwa hasil OR 56,000 artinya bayi yang tidak diberi ASI memiliki peluang hampir 56 
Faletehan Health Journal, 8 (2) (2021) 115-121

kali lebih besar menyebabkan bayi mengalami hiperbilirubin dibandingkan dengan bayi yang diberi ASI. Disimpulkan bahwa pemberian ASI menjadi faktor yang paling dominan terhadap kejadian hiperbilirubin dibandingkan dengan usia kehamilan, berat lahir bayi dan jenis persalinan. Pemberian ASI yang lebih sering mencegah bayi mengalami dehidrasi dan kekurangan asupan kalori. Terlambatnya bayi mendapatkan nutrisi (ASI) mengakibatkan bilirubin direk yang sudah mencapai usus didalam usus inilah bilirubin direk diubah menjadi bilirubin indirek yang akan diserap kembali ke dalam darah sehingga hiperbilirubin menetap, tidak terikat oleh makanan dan tidak dikeluarkan melalui anus bersama makanan .

Hasil penelitian ini sejalan dengan hasil penelitian Indanah (2019) bahwa bahwa rata rata penurunan kadar bilirubin bayi yang diberikan ASI tiap 2 jam adalah 7,17 mg/dl. Pada bayi yang diberikan ASI tiap 3 jam, rata rata penurunan kadar bilirubin bayi adalah 7,01 $\mathrm{mg} / \mathrm{dl}$, hal tersebut menunjukkan Pemberian ASI tiap 2 jam efektif dalam menurunkan kadar bilirubin bayi dengan hiperbilirubinemia dengan $p$ value $0,000(\alpha: 0,05)$ (Indanah, Karyati, and Yusminah 2019). Selain itu referensi data angka kejadian hiperbilirubin pada bayi baru lahir di RS Hasan Sadikin Bandung pada tahun 2014 menunjukan penurunan sekitar 8,04\% dibandingkan dengan tahun 2010 yang dipengaruhi oleh implementasi dari upaya preventif cukup baik terhadap kejadian hiperbilirubin, yakni salah satunya adalah upaya untuk pemberian ASI (Nurani et al. 2017)

Hiperbilirubinemia adalah kadar bilirubin yang dapat menimbulkan efek patologi, Untuk mengendalikan kadar bilirubin pada bayi baru lahir dapat dilakukan pemberian ASI sedini mungkin. Pemberian ASI pada bayi dianjurkan 2-3 jam sekali atau 8-12 kali dalam sehari. Semakin cepat bayi diberikan ASI maka harapannya semakin cepat dalam pengeluaran meconium, keterlambatan pengeluaran mekonium dan penurunan frekuensi aliran mekonium dapat meningkatkan sirkulasi enterohepatik dan berkontribusi pada perkembangan penyakit kuning (Siyah Bilgin et al. 2013). Hiperbilirubinemia adalah kadar bilirubin yang dapat menimbulkan efek patologi, Untuk mengendalikan kadar bilirubin pada bayi baru lahir dapat dilakukan pemberian ASI sedini mungkin. Pemberian ASI pada bayi dianjurkan 2-3 jam sekali atau 8-12 kali dalam sehari.

\section{Analisis Data Multivariat}

Tabel 6 menunjukkan terdapat hubungan yang bermakna antara usia kehamilan (P : 0,006), berat lahir bayi (P:0,002), jenis persalinan (P:0,001) dan pemberian ASI (P:0,000) dengan kejadian hiperbilirubin. Faktor dominan yang berpengaruh terhadap kejadian hiperbilirubin adalah pemberian ASI dengan nilai Odds Ratio (OR) variabel pemberian ASI adalah 54,914, artinya bayi yang tidak diberi ASI memiliki peluang untuk mengalami hiperbilirubin sebesar hampir 55 kali lebih besar dibandingkan bayi yang diberi ASI setelah dikontrol variabel usia kehamilan, berat lahir bayi dan jenis persalinan.

Berdasarkan hasil analisis multivariat menunjukkan bahwa pemberian ASI menjadi factor dominan dalam mempengaruhi kejadian hiperbilirubin. Berdasarkan hasil ini tentunya memberikan beberapa implikasi terhadap tenaga Kesehatan dalam mencegah terjadinya hiperbilirubi pada bayi baru lahir. Tenaga Kesehatan dapat memberikan motivasi pada ibu dengan bayi yang mengalami hiperbilirubin untuk tidak panik, tetap memberikan ASI on demand kapan pun dan dimana pun agar hiperbilirubin dapat teratasi dengan baik. Selain itu, Pemberian ASI sedini mungkin dapat mencegah kejadian hiperbilirubin. Melalui Inisiasi Menyusu Dini (IMD), bayi mendapatkan kolostrum yang bermanfaat untuk kekebalan tubuh sehingga dapat mencegah bayi mengalami infeksi dan penyakit lainnya diantaranya yaitu hiperbilirubin. Bayi- bayi yang disusui dalam satu jam pertama kelahiran dan terus disusui secara teratur akan cenderung lebih awal mengeluarkan mekonium dan mengalami kejadian sakit kuning fisiologi yang lebih rendah.

Tabel 2: Hubungan antara Usia Kehamilan dengan Kejadian Hiperbilirubin

\begin{tabular}{|c|c|c|c|c|c|c|c|c|c|}
\hline \multirow{3}{*}{ Usia Kehamilan } & \multicolumn{4}{|c|}{ Kejadian Hiperbilirubin } & \multirow{2}{*}{\multicolumn{2}{|c|}{ Total }} & \multirow{3}{*}{$P$ Value } & \multirow{3}{*}{ OR } & \multirow{3}{*}{ CI } \\
\hline & \multicolumn{2}{|c|}{ Ya } & \multicolumn{2}{|c|}{ Tidak } & & & & & \\
\hline & $\mathbf{n}$ & $\%$ & $\mathbf{n}$ & $\%$ & $\mathrm{n}$ & $\%$ & & & \\
\hline Preterm $(<37$ minggu $)$ & 12 & 54,5 & 8 & 18,2 & 20 & 30,3 & & & \\
\hline Aterm $(\geq 37$ minggu $)$ & 10 & 45,5 & 36 & 81,8 & 46 & 69,7 & 0,006 & 5,4 & $1,733-16,882$ \\
\hline Total & 22 & 100 & 44 & 100 & 66 & 100 & & & \\
\hline
\end{tabular}


Tabel 3: Hubungan antara Berat Lahir Bayi dengan Kejadian Hiperbilirubin

\begin{tabular}{|c|c|c|c|c|c|c|c|c|c|}
\hline \multirow{3}{*}{ Berat Lahir Bayi } & \multicolumn{4}{|c|}{ Kejadian Hiperbilirubin } & \multirow{2}{*}{\multicolumn{2}{|c|}{ Total }} & \multirow{3}{*}{$P$ Value } & \multirow{3}{*}{ OR } & \multirow{3}{*}{ CI } \\
\hline & \multicolumn{2}{|c|}{ Ya } & \multicolumn{2}{|c|}{ Tidak } & & & & & \\
\hline & $\mathbf{n}$ & $\%$ & $\mathbf{n}$ & $\%$ & $\mathrm{n}$ & $\%$ & & & \\
\hline BBLR & 13 & 59 & 8 & 18,2 & 21 & 31,8 & & & \\
\hline Tidak BBLR & 9 & 41 & 36 & 81,8 & 45 & 68,2 & 0,002 & 6,500 & $2,070-20,410$ \\
\hline Total & 22 & 100 & 44 & 100 & 66 & 100 & & & \\
\hline
\end{tabular}

Tabel 4: Hubungan antara Jenis Persalinan dengan Kejadian Hiperbilirubin

\begin{tabular}{|c|c|c|c|c|c|c|c|c|c|}
\hline \multirow{3}{*}{ Jenis Persalinan } & \multicolumn{4}{|c|}{ Kejadian Hiperbilirubin } & \multirow{2}{*}{\multicolumn{2}{|c|}{ Total }} & \multirow{3}{*}{$P$ Value } & \multirow{3}{*}{$\mathbf{O R}$} & \multirow{3}{*}{ CI } \\
\hline & \multicolumn{2}{|c|}{ Ya } & \multicolumn{2}{|c|}{ Tidak } & & & & & \\
\hline & $\mathbf{n}$ & $\%$ & $\mathbf{n}$ & $\%$ & $\mathrm{n}$ & $\%$ & & & \\
\hline $\begin{array}{l}\text { Tidak Normal (SC, } \\
\text { Vakum) }\end{array}$ & 18 & 81,8 & 16 & 36,4 & 34 & 51,5 & & & \\
\hline $\begin{array}{l}\text { Normal (Persalinan } \\
\text { Pervaginaan) }\end{array}$ & 4 & 18,2 & 28 & 63,6 & 32 & 48,5 & 0,001 & 7,875 & $2,267-27,361$ \\
\hline Total & 22 & 100 & 44 & 100 & 66 & 100 & & & \\
\hline
\end{tabular}

Tabel 5: Hubungan antara Pemberian ASI dengan Kejadian Hiperbilirubin

\begin{tabular}{|c|c|c|c|c|c|c|c|c|c|}
\hline \multirow{3}{*}{ Pemberian ASI } & \multicolumn{4}{|c|}{ Kejadian Hiperbilirubin } & \multirow{2}{*}{\multicolumn{2}{|c|}{ Total }} & \multirow{3}{*}{$P$ Value } & \multirow{3}{*}{ OR } & \multirow{3}{*}{ CI } \\
\hline & \multicolumn{2}{|c|}{$\mathbf{Y a}$} & \multicolumn{2}{|c|}{ Tidak } & & & & & \\
\hline & n & $\%$ & $\mathbf{n}$ & $\%$ & $\mathrm{n}$ & $\%$ & & & \\
\hline Tidak Diberi ASI & 16 & 72,7 & 2 & 4,5 & 18 & 27,3 & \multirow{3}{*}{0,000} & \multirow{3}{*}{56,000} & \multirow{3}{*}{$10,223-306.769$} \\
\hline Diberi ASI & 6 & 27,3 & 42 & 95,5 & 48 & 72,7 & & & \\
\hline Total & 22 & 100 & 44 & 100 & 66 & 100 & & & \\
\hline
\end{tabular}

Tabel 6: Analisis Data Multivariat

\begin{tabular}{|c|c|c|c|c|c|c|}
\hline \multirow[b]{2}{*}{ Variabel } & \multicolumn{3}{|c|}{ Bivariat } & \multicolumn{3}{|c|}{ Multivariat } \\
\hline & P Value & $\begin{array}{c}\text { OR } \\
\text { Crude }\end{array}$ & CI & $P$ Value & OR Adj & CI \\
\hline $\begin{array}{l}\text { Usia Kehamilan } \\
\text { Preterm }(<37 \text { minggu }) \\
\text { Aterm }(\geq 37 \text { minggu })\end{array}$ & 0,006 & 5,4 & $1,733-16,882$ & 0,708 & 0,646 & $0,066-6,345$ \\
\hline $\begin{array}{l}\text { Berat Lahir Bayi } \\
\text { BBLR } \\
\text { Tidak BBLR } \\
\end{array}$ & 0,002 & 6,500 & $2,070-20,410$ & 0,299 & 3,508 & $0,329-37,445$ \\
\hline $\begin{array}{l}\text { Jenis Persalinan } \\
\text { Tidak normal (SC, } \\
\text { Vakum) } \\
\text { Normal(persalinan } \\
\text { pervaginam) }\end{array}$ & 0,001 & 7,875 & $2,267-27,361$ & 0,149 & 4,593 & $0,578-36,504$ \\
\hline $\begin{array}{l}\text { Pemberian ASI } \\
\text { Tidak diberi ASI } \\
\text { Diberi ASI }\end{array}$ & 0,000 & 56,000 & $10,223-306.769$ & 0,000 & 54,914 & $7,612-396.167$ \\
\hline
\end{tabular}

\section{Simpulan}

Berdasarkan hasil penelitian dapat disimpulkan bahwa ada hubungan yang bermakna antara usia kehamilan, berat lahir bayi, jenis persalinan dan pemberian ASI dengan kejadian hiperbilirubin. Faktor yang paling dominan dan berpengaruh terhadap kejadian hiperbilirubin adalah pemberian ASI. IMD yang dilanjutkan 
Faletehan Health Journal, 8 (2) (2021) 115-121

dengan pemberian ASI eksklusif dapat menjadi upaya yang dilakukan untuk mencegak terjadinya hiperbilirubin. Memotivasi ibu untuk terus memberikan ASI on deman pada saat bayi mengalami hiperbilirubin menjadi salah satu upaya untuk mengatasi bayi dengan hiperbilirubin.

\section{Referensi}

Cholifah, Cholifah. 2017. "Faktor-Faktor Yang Berpengaruh Terhadap Hiperbilirubinemia Di RS Muhammadiyah Gersik." Jurnal Kebidanan Midwiferia 3(1):14-25.

Cholifah, Cholifah, and Alfinda Ayu Hadikasari. 2016. "Hubungan Anemia, Status Gizi, Olahraga Dan Pengetahuan Dengan Kejadian Dismenore Pada Remaja Putri." Jurnal Kebidanan Midwiferia 1(1):30-44.

Dinas Kesehatan Provinsi Banten. 2017. "Profil Kesehatan Provinsi Banten Tahun 2017."

Indanah, I., Sri Karyati, and Y. Yusminah. 2019. "Efektifitas Pemberian ASI Terhadap Penurunan Kadar Bilirubin." Proceeding of The URECOL 565-71.

Indrasari, Nelly. 2016. "Faktor Resiko Pada Kejadian Berat Badan Lahir Rendah (BBLR)." Jurnal Ilmiah Keperawatan Sai Betik 8(2):114-23.

Kementrian Kesehatan RI. 2017. Survey Demografi Kesehatan Indonesia Tahun 2017.

Khan, M. W., M. Arbab, M. Murad, M. B. Khan, and S. Abdullah. 2014. "Study of Factors Affecting and Causing Low Birth Weight." Journal of Scientific Research 6(2):387-94.

Madiastuti, Marini, and Sri Chalada. 2018. "Faktor-Faktor Yang Berhubungan Dengan Kejadian Neonatus Hiperbilirubin Di Rsb Pasutri Bogor Provinsi Jawa Barat Tahun 2016." Ilmu Dan Budaya 40(55).

Marmi. 2012. Asuhan Neonatus, Bayi, Balita Dan Anak Pra Sekolah. Yogyakarta: Pustaka Pelajar.

Maryunani, A. 2014. Asuhan Kegawatdaruratan Maternal Dan Neonatus. Jakarta: CV. Trans Info Media.

Nurani, Namira Bening, Fiva Aprillia Kadi, and Tiene Rostini. 2017. "Incidence of Neonatal Hyperbilirubinemia Based on Their Characteristics at Dr. Hasan Sadikin General Hospital Bandung Indonesia." Althea Medical Journal 4(3):431-34.

Prawiranegara, RSUD Drajat. 2019. "Buku Register Ruang Perinatologi Tahun 2019.”
Roselina, Elsa. Saroha Pinem dan Rochimah. 2013. "Hubungan Jenis Persalinan Dan Prematuritas Dengan Hiperbilirubinemia Di RS Persahabatan." Jurnal Vokasi Indonesia.

Siyah Bilgin, Betul, Ozge Altun Koroglu, Mehmet Yalaz, Semra Karaman, and Nilgun Kultursay. 2013. "Factors Affecting Bilirubin Levels during First 48 Hours of Life in Healthy Infants." BioMed Research International 2013.

Sulistyorini, Suci. 2018. "Hubungan berat badan lahir bayi dan usia gestasi dengan kejadian ikterus neonatorum di RS. Muhammadiyah Palembang." Masker Medika 6(2):377-82. 